JOURNAL OF APPLIED MECIANICAL
ENGINEERING AND RENEWABLE
ISAS Vol. 1 No. 1, Februari $2021.6-15$

\title{
Analisis Perbandingan Teoritis Performansi Daya Mesin Mobil dan Konsumsi Bahan Bakar Spesifik Berteknologi VVT-i dan Non VVT-i
}

\author{
Yudhi Chandra Dwiaji ${ }^{1}$, Oka Mahendra ${ }^{2}$ \\ 1,2 Jurusan Teknik Mesin, Fakultas Teknik, Universitas Mercubuana \\ ${ }^{1}$ yudhichandra7@gmail.com*
}

\begin{abstract}
VVT-i (Variable Valve Timing with Intelligent) technology basically works to optimize engine torque at every speed and driving conditions. The mechanism will eventually produce more efficient fuel consumption and lower exhaust emissions. The workings of VVT-i technology are quite simple, namely to calculate the optimal valve opening time, the ECU (Electronic Control Unit) will adjust the engine speed, air intake volume, throttle position and water temperature. In order for the valve timing target to always be realized, the crankshaft position sensor provides a signal that is a correction response. This VVT-i system will correct valve timing or fuel and air inlet lines. Adapted to the gas pedal footing and load borne to produce optimal torque in each rotation and engine load. This technology is also claimed to have excess power that is far more optimal and saves fuel consumption, and is environmentally friendly.
\end{abstract}

Keywords: VVT-i, Valve Timing, ECU, Crankshaft.

\begin{abstract}
Abstrak
Mesin berteknologi VVT-i (Variable Valve Timing with Intellegence) pada dasarnya bekerja mengoptimalkan torsi mesin pada setiap kecepatan serta kondisi mengemudi. Mekanisme tersebut akhirnya akan membuahkan konsumsi BBM menjadi lebih efisien serta emisi gas buang menjadi lebih rendah. Cara kerja teknologi VVT-i cukup sederhana, yaitu untuk menghitung waktu buka tutup katup (Valve Timing) yang optimal, ECU (Electronic Control Unit) akan menyesuaikan dengan kecepatan mesin, volume udara masuk, posisi throttle dan temperatur air. Agar target valve timing senantiasa terwujud, sensor posisi crankshaft memberikan sinyal yang menjadi respon koreksi. Sistem VVT-i ini akan mengoreksi valve timing atau jalur keluar masuk bahan bakar dan udara. Disesuaikan dengan pijakan pedal gas dan beban yang ditanggung untuk menghasilkan torsi optimal di tiap putaran dan beban mesin. Teknologi ini juga diklaim memiliki kelebihan tenaga yang jauh lebih optimal dan hemat konsumsi bahan bakar, serta ramah lingkungan.
\end{abstract}

Kata kunci: VVT-i, Valve Timing, ECU, Crankshaft.

\section{Pendahuluan}

Sebagaimana kita ketahui bahwa moda transportasi hemat bahan bakar dan ramah lingkungan. Mekanisme yang sangat diminati sekarang adalah kendaraan atau cara kerja mesin VVT-i ini terbilang cukup bermotor dan bermobil. Dimana orang membutuhkan sederhana. Untuk menghitung waktu buka tutup katup waktu untuk segera tiba ketujuan untuk bertemu (valve timing) secara tepat, teknologi ini menggunakan keluarga atau terlebih hanya keperluan bisnis semata. ECU (Electronic Control Unit). ECU ini tugasnya untuk Bahkan terkadang kita jumpai ada segelintir orang yang mengatur kecepatan mesin, volume udara masuk, posisi membayar lebih hanya untuk mencapai keperluannya throttle (akselerator) dan suhu air. Supaya target valve pada suatu tempat. Seiring dengan perkembangan timing tercapai, sensor posisi chamshaft atau crankshaft teknologi pada mesin kendaraan mobil, sebaiknya telah akan memberikan sinyal sebagai respon koreksi. Secara diikuti pula oleh kemajuan teknologi atau kemampuan otomatis teknologi VVT-i akan terus mengoreksi jalur kebutuhan kendaraan salah satunya teknologi VVT-i keluar masuknya bahan bakar dan udara disesuaikan atau Variable Valve Timing- Intellegent.

dengan injakan pedal gas untuk menghasilkan torsi yang

Teknologi VVT-i merupakan teknologi yang optimal disetiap putaran roda. Dengan cara kerja yang mengatur sistem kerja katup pemasukan bahan bakar simple ini, teknologi VVT-i memberikan hasil yang (Intake) secara elektronik baik dalam hal waktu maupun efisien dan memuaskan pada mesin mobil. Teknologi ukuran buka tutup katup sesuai dengan besar putaran VVT-i membuat mesin lebih bertenaga disetiap putaran mesin sehingga menghasilkan tenaga yang optimal, 
karena sistem katup mendukung proses pembakaran agar lebih efektif.

\section{Tinjauan Pustaka}

Mesin berteknologi VVT-i ( Variable Valve Timing with Intellegence) adalah mesin berteknologi variable valve timing yang dikembangkan oleh Toyota [1]. VVTi menggantikan teknologi VVT Toyota yang sudah mulai diterapkan tahun 1991 di mesin Toyota 4A-GE 5 Silinder. Mesin yang sudah VVT-i diklaim membuat mesin semakin efisien dan bertenaga, ramah lingkungan serta hemat bahan bakar. [1]-[3]

Dasar dari VVT-i adalah mengoptimalkan torsi mesin pada setiap kecepatan dan kondisi pengemudian yang membuat konsumsi BBM menjadi lebih efisien dan menurunkan tingkat emisi bahan bakar serendah mungkin. Cara kerja mesin ini cukup sederhana, untuk menghitung waktu buka tutup katup (Valve Timing) yang optimal, ECU (Electronic Control Unit) menyesuaikan dengan kecepatan mesin, volume udara masuk, posisi throttle dan temperatur air. Agar target valve timing senantiasa terwujud, sensor posisi crankshaft memberikan sinyal yang menjadi respon koreksi. Bahasa sederhananya sistem VVT-i akan terus mengoreksi valve timing atau jalur keluar masuk bahan bakar dan udara [4]-[7].

1.1. Analisis Termodinamika [8]

Proses 0 - 1: Langkah hisap, tekanan konstan, katup buang tertutup sedangkan katup masuk terbuka. Udara dianggap sebagai gas ideal. Udara dihisap masuk ke silinder dengan tekanan 1,03 atm atau 104, $3647 \mathrm{kPa}$ pada temperatur $27^{\circ} \mathrm{C}$ atau $300 \mathrm{~K}$, maka: $P_{0}=P_{1}=104$, $3647 \mathrm{kPa}$

Volume sisa :

Didefenisikan sebagai volume minimum silinder pada saat torak berada di titik mati atas (TMA). maka besarnya volume sisa:

$r_{a}=\frac{V_{C}+V_{d}}{V_{c}}$

Volume pada titik 1:

Merupakan hasil penjumlahan volume langkah $(V d)$ dengan volume sisa $\left(V_{c}\right)$.

$V_{1}=V_{C}+V_{d}$

Massa campuran bahan bakar dan udara:

Dengan tekanan 1 atm atau 104 volume silinder pada temperatur $300 \mathrm{~K}$, massa campuran bahan bakar dan udara adalah :

$m_{m}=\frac{P_{1} V_{1}}{R T_{1}}$

Massa udara pembakaran dan massa bahan bakar:

Sejumlah udara dihisap masuk ke dalam silinder tekanan di dalam silinder. dengan perbandingan 14,7:1 terhadap bahan bakar pada $P_{3}=P_{2} \frac{T_{3}}{T_{2}}$
tekanan konstan. Udara mengisi ruangan silinder yang

(3) $m_{m} C_{V}\left(T_{3}-T_{2}\right)$, maka $T_{3}$ dapat diketahui :

(2) diasumsikan terjadi pembakaran sempurna, $\eta_{a}=1$.

$Q_{\text {in }}=m_{f} Q_{H V} \eta_{a}$

Proses 1 - 2: Langkah kompresi isentropik, semua katup tertutup. Torak bergerak darititik mati bawah (TMB) ke titik mati atas (TMA). Tekanan pada titik 2 : Campuran bahan bakar dan udara yang berada di dalam silinder ditekan dandimampatkan oleh torak yang bergerak ke itik mati atas (TMA). Akibatnya, tekanan dalam silinder menjadi $P 2$.

Temperatur pada titik 2 :

Campuran bahan bakar dan udara yang dimanfaatkan oleh torak yang bergerak ke titik mati atas (TMA) juga mengakibatkan suhu dalam silinder naik menjadi $T_{2}$ :

$T_{2}=T_{1}\left(r_{c}\right)^{k-1}$

Volume pada titik 2:

$V_{2}=\frac{m_{m} R T_{2}}{P_{2}}$

Kerja persiklus $1-2$ :

Kerja yang diserap selama langkah kompresi isentropik untuk satu silinder dalam satu siklus adalah sebagai berikut :

Proses 2 - 3: Penambahan kalor pada volume konstan.

Kalor masuk:

Bahan bakar yang digunakan adalah PERTAMAX

Temperatur pada titik 3 :

$T_{3}=\frac{Q_{i n}+m_{m} C_{V} T_{2}}{m_{m} C_{V}}$

Volume pada titik 3:

Dari diagram P-v siklus Otto ideal dapat dilihat bahwa $V_{3}$ sama dengan $V_{2}$.

(4) Tekanan pada titik 3:

Seiring dengan bertambahnya temperatur selama siklus tertutup volume konstan, maka bertambah pula bertambah besar seiring bergeraknya torak dari titik mati atas (TMA) ke titik mati bawah (TMB). Untuk $1 \mathrm{~kg}$ siklus.

bahan bakar diperlukan $14,7 \mathrm{~kg}$ udara dengan massa

campuran $(\mathrm{mm})$ serta diasumsikan residu gas hasil $P_{3}=P_{\text {maksimum }}$ 
Proses 3 - 4: Langkah Ekspansi isentropik

Temperatur pada titik 4:

Setelah torak mencapai titik mati bawah (TMB) sejumlah kalor dikeluarkan dari dalam silinder sehingga temperatur fluida kerja akan turun menjadi $T 4$.

$$
T_{4}=T_{3}\left(\frac{1}{r_{c}}\right)^{k-1}
$$

Tekanan pada titik 4:

Begitu juga dengan tekanan di dalam silinder, mengalami penurunan menjadi $P_{4}$.

$P_{4}=P_{3}\left(\frac{1}{r_{c}}\right)^{k}$

Volume pada titik 4:

Dari diagram P-v siklus ideal Otto dapat dilihat bahwa $V 4$ sama dengan $V 1$.

Kerja persiklus $3-4$ :

Tekanan tinggi yang disertai pembakaran di dalam silinder, membuat piston terdorong kembali ke titik mati bawah (TMB). Gerakan piston tersebut menghasilkan kerja sebesar $W_{3-4}$.

$$
W_{3-4}=\frac{m_{m} R\left(T_{4}-T_{3}\right)}{1-k}
$$

Proses 4 - 1: Proses pembuangan kalor pada volume konstan

Kalor yang dibuang:

Pada saat torak mencapai titik mati bawah (TMB)

kalor dibuang sebesar $Q_{4-1}$.

$Q_{4-1}=Q_{\text {out }}=m_{m} C_{v}\left(T_{1}-T_{4}\right)$

Kerja satu siklus :

Kerja yang dihasilkan dari satu siklus $W_{\text {nett }}$ : Kerja netto dalam satu siklus $(k J)$ termodinamika adalah sebagai berikut:

$W_{\text {nett }}=W_{1-2}+W_{3-4}$

(18) 1.4. Efisiensi Volumetrik

Daya poros dapat diukur secara tidak langsung

Efisiensi volumetrik (Volumetric Efficiency, VE) dengan dinamometer. Dinamometer sebenarnya sebuah mesin (dalam hal ini mesin piston) dapat mengukur momen torsi motor. Oleh karena itu dikatakan sebagai ukuran seberapa banyak udara yang memerlukan variabel lain yaitu putaran poros motor masuk ke dalam silinder/ruang bakar. Secara teoritis yang dapat diukur dengan tachometer. Hubungan antara banyaknya bahan bakar dan udara yang masuk ke dalam momen torsi dengan daya motor adalah sebagai berikut: silinder sama dengan volume langkahnya. Akan tetapi, $W_{b}=2 \pi \cdot n \cdot T$

$\mathrm{T} \quad$ : Momen torsi $(\mathrm{Nm})$

$W_{b} \quad$ : Daya poros efektif $(\mathrm{kW})$

n : Putaran poros engkol (rpm)

(19) kenyatananya lebih sedikit karena dipengaruhi oleh beberapa faktor, yaitu:

1. Tekanan udara

2. Temperatur

3. Panjang saluran

4. Bentuk saluran dan

5. Sisa hasil pembakaran di dalam silinder pada proses yang mendahului.

Ukurannya adalah massa/berat udara bukan volumenya. Jika ukurannya volume, tentu saja jumlah udara selalu tetap yaitu sama dengan volume silinder.

(20) Sebagai contoh, untuk mesin berkapasitas $100 \mathrm{cc}$, jumlah udaranya $100 \mathrm{cc}$. Jumlah udara dengan volume sama dan massa yang berbeda artinya massa jenisnya berbeda. Namun, ukuran yang paling sering digunakan bukan massa atau massa jenis melainkan tekanan karena tekanan dapat langsung diukur oleh sensor tekanan. Tekanan tinggi artinya massa jenisnya besar dan tekanan rendah artinya massa jenisnya kecil [9], [10]. 


$$
\eta_{v}=\frac{m_{a}}{\rho_{a} V_{d}}
$$

Dimana :

$\eta_{v} \quad$ : Efisiensi Volumetrik

$m_{a} \quad$ : Massa jenis udara $(\mathrm{kg} / \mathrm{m} 3)$

$\rho_{a} \quad:$ DentitasUdara $(\mathrm{kg} / \mathrm{m} 3)$

$V_{d} \quad$ : Besar Volume Langkah $(\mathrm{m} 3)$

\subsection{Efisiensi Mekanis}

Efisiensi mekanis mengindikasikan seberapa besar daya yang digunakan untuk menggerakkan mesin itu sendiri. Sebagian kecil daya yang dihasilkan motor digunakan oleh motor itu sendiri untuk menggerakkan bagian-bagian yang bergerak, yaitu melawan gaya gesek di antara bagian-bagian tersebut. Daya yang tersisa merupakan daya output yang dapat diukur dengan dinamometer. Selisih antara daya output dengan daya yang dihasilkan di dalam silinder merupakan rugi-rugi mekanis.

Dimana

$$
\eta_{m}=\frac{W_{b}}{W_{i}}
$$

$W_{b} \quad$ : Daya Poros (kW)

$W_{i} \quad$ : Daya Indikator $(\mathrm{kW})$

\section{Metodologi Penelitian}

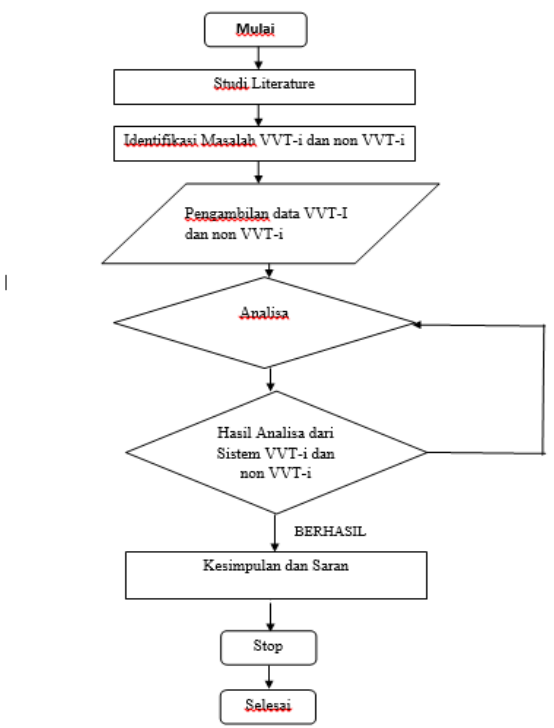

Gambar 1. Diagram alir metode penelitian

Dari diagram alir pada gambar 1 dapat diketahui bahwa terdapat empat tahapan dalam melakukan analisis performansi mesin mobil, yaitu terdiri dari identifikasi masalah pada sistem VVT-I dan NON VVT-I yang akan di analisis, pengumpulan data yang dibutuhkan untuk keperluan analisis, melakukan analisis daya dan konsumsi bahan bakar pada sistem VVT-I dan NON VVT-I dengan menggunakan metode perhitungan manual dan dengan bantuan program komputer dynotest, serta menyimpulkan hasil yang telah dilakukan di bab sebelumnya.

\section{(24) 3. Hasil dan Pembahasan}

\subsection{Pengumpulan Data}

Data berikut meliputi data dari hasil penelitian yang dilakukan di Bengkel Rev Engineering menggunakan mesin Dynotest .

\subsection{Mesin VVT-i}

\section{Analisa Termodinamika}

Proses 0 - 1: Langkah hisap, tekanan konstan, katup buang tertutup sedangkan katup masuk terbuka. Udara dianggap sebagai gas ideal. Udara dihisap masuk ke silinder dengan tekanan 1,03 atm atau 104, $3647 \mathrm{kPa}$ pada temperatur $27^{\circ} \mathrm{C}$ atau $300 \mathrm{~K}$, maka: $P_{0}=P_{1}=104$, $3647 \mathrm{kPa}$

$$
\begin{aligned}
T_{1} & =300 \mathrm{~K} \\
r_{c} & =10 \\
\mathrm{~B} & =7,2 \mathrm{~cm} \\
\mathrm{~S} & =9,18 \mathrm{~cm} \\
\mathrm{R} & =0,287 \mathrm{~kJ} / \mathrm{kg}-\mathrm{K} \\
C_{V} & =0,718 \mathrm{~kJ} / \mathrm{kg}-\mathrm{K}
\end{aligned}
$$

Volume langkah:

Merupakan volume dari langkah torak dari titik mati bawah (TMB) ke titik mati atas(TMA). Kapasitas 4 silinder adalah $1498 c c$, maka volume langkah untuk satu silinder:

$$
\begin{aligned}
& V_{d}=\frac{1498}{4} \\
& V_{d}=374,5 c c=0,0003745 \mathrm{~m}^{3}
\end{aligned}
$$

Volume sisa :

Didefenisikan sebagai volume minimum silinder pada saat torak berada di titik matiatas (TMA). Dengan rasio kompresi sebesar 10:1 dan volume langkah sebesar $0,0003745 \mathrm{~m}^{3}$ maka besarnya volume sisa:

$$
\begin{aligned}
r_{a} & =\frac{V_{C}+V_{d}}{V_{c}} \\
& =\frac{V_{C}+0,0003745}{V_{c}}=10 \\
V_{C} & =0,00004161 \mathrm{~m}^{3}
\end{aligned}
$$

Volume pada titik 1:

Merupakan hasil penjumlahan volume langkah $(V d)$ dengan volume sisa $\left(V_{c}\right)$.

$$
\begin{aligned}
V_{1} & =V_{C}+V_{d} \\
& =0,00004161+0,0003745 \\
& =0,00041611 \mathrm{~m}^{3}
\end{aligned}
$$

Massa campuran bahan bakar dan udara:

Dengan tekanan 1 atm atau $104,3647 \mathrm{kPa}$ dan volume silinder $0,00041611 \mathrm{~m}^{3}$ pada temperatur $300 \mathrm{~K}$, massa campuran bahan bakar dan udara adalah :

$$
\begin{aligned}
m_{m} & =\frac{P_{1} V_{1}}{R T_{1}} \\
& =\frac{104,3647 \times 0,00041611}{0,287 \times 300} \\
& =0,0005043 \mathrm{~kg}
\end{aligned}
$$


Massa udara pembakaran dan massa bahan bakar :

Proses 2 - 3: Penambahan kalor pada volume konstan.

Sejumlah udara dihisap masuk ke dalam silinder Kalor masuk:

dengan perbandingan 14,7:1 terhadap bahan bakar pada Bahan bakar yang digunakan adalah PERTAMAX tekanan konstan. Udara mengisi ruangan silinder yang dengan nilai kalori bahan bakar $46000 \mathrm{~kJ} / \mathrm{kg}$ dan bertambah besar seiring bergeraknya torak dari titik mati diasumsikan terjadi pembakaran sempurna, $\eta_{a}=1$.

atas (TMA) ke titik mati bawah (TMB). Untuk $1 \mathrm{~kg}$ bahan $Q_{i n}=m_{f} Q_{H V} \eta_{a}$

bakar diperlukan $14,7 \mathrm{~kg}$ udara dengan massa campuran ( $\mathrm{mm}$ ) sebesar $0,0005043 \mathrm{~kg}$ serta diasumsikan residu gas hasil pembakaran 4\% dari siklus sebelumnya, maka Temperatur pada titik 3:

besarnya massa udara dan massa bahan bakar adalah:

$m_{a}=\left(\frac{14,7}{15,7}\right) \times 0,96 \times 0,0005043 \mathrm{~kg}=0,00045329 \mathrm{~kg}$

$m_{f}=\left(\frac{1}{15,7}\right) \times 1 \times 0,0005043 \mathrm{~kg}=0,00003212 \mathrm{~kg}$

Densitas udara $\left(P_{a}\right)$

Tekanan dan temperatur udara sekitar mesin dapat digunakan untuk mencari densitas udara dengan persamaan matematika sebagai berikut:

$$
\begin{aligned}
P_{a} & =\frac{P_{1}}{R T_{1}} \\
& =\frac{104,3647}{0,287 \times 300} \\
& =1,2121 \mathrm{~kg} / \mathrm{m}^{3}
\end{aligned}
$$

Proses 1-2 :Langkah kompresi isentropik, semua katup tertutup. Torak bergerak darititik mati bawah (TMB) ke titik mati atas (TMA). Tekanan pada titik 2 : Campuran bahan bakar dan udara yang berada di dalam silinder ditekan dandimampatkan oleh torak yang bergerak ke titik mati atas (TMA). Akibatnya, tekanan dalam silinder naik menjadi $P 2$.

$$
\begin{aligned}
P_{2} & =P_{1}\left(r_{c}\right)^{k} \\
& =104,3647 x(10)^{1,4} \\
& =2621,5227 \mathrm{kPa}
\end{aligned}
$$

Temperatur pada titik 2 :

Campuran bahan bakar dan udara yang dimanfaatkan oleh torak yang bergerak ke titik mati atas (TMA) juga mengakibatkan suhu dalam silinder naik menjadi $T_{2}$ :

$$
\begin{aligned}
& T_{2}=T_{1}\left(r_{c}\right)^{k-1} \\
& \quad=300 \times(10)^{1,4-1} \\
& =753,5659 \mathrm{~K}
\end{aligned}
$$

Volume pada titik 2 :

$$
\begin{aligned}
V_{2} & =\frac{m_{m} R T_{2}}{P_{2}} \\
& =\frac{0,0005043 \times 0,287 \times 753,5659}{2621,5227} \\
& =0,00004160 \mathrm{~m}^{3} \\
V_{2} & =V_{C}
\end{aligned}
$$

Kerja persiklus $1-2$ :

Kerja yang diserap selama langkah kompresi isentropik untuk satu silinder dalam satu siklus adalah sebagai berikut :

$$
\begin{aligned}
W_{1-2} & =\frac{m_{m} R\left(T_{2}-T_{1}\right)}{1-k} \\
W_{1-2} & =\frac{0,0005043 \times 0,287(753,5659-300)}{1-1,4} \\
& =(-0,1641) \mathrm{Kj}
\end{aligned}
$$

Dengan menggunakan persamaan matematika $Q_{\text {in }}=$ $m_{m} C_{V}\left(T_{3}-T_{2}\right)$, maka $T_{3}$ dapat diketahui :

$T_{3}=\frac{Q_{\text {in }}+m_{m} C_{V} T_{2}}{m_{m} C_{V}}$

$T_{3}=\frac{1,4775+0,0005043 \times 0,718 \times 753,5659}{0,0005043 \times 0,718}$

$T_{3}=4834,0724 \mathrm{~K}$

$T_{3}=T_{\text {maks }}$

Volume pada titik 3:

Dari diagram P-v siklus Otto ideal dapat dilihat bahwa $V_{3}$ sama dengan $V_{2}$.

$V_{3}=V_{2}=0,00004160 \mathrm{~m}^{3}$

Tekanan pada titik 3 :

Seiring dengan bertambahnya temperatur selama siklus tertutup volume konstan, maka bertambah pula tekanan di dalam silinder.

$$
\begin{aligned}
& P_{3}=P_{2} \frac{T_{3}}{T_{2}} \\
& =2621,5227\left(\frac{4834,0724}{753,5659}\right) \\
& =16816,8842 \mathrm{kPa}
\end{aligned}
$$

Tekanan tersebut merupakan tekanan maksimum siklus.

$P_{3}=P_{\text {maksimum }}$

Proses 3 - 4: Langkah Ekspansi isentropik

Temperatur pada titik 4:

Setelah torak mencapai titik mati bawah (TMB) sejumlah kalor dikeluarkan dari dalam silinder sehingga temperatur fluida kerja akan turun menjadi $T 4$.

$$
\begin{aligned}
T_{4} & =T_{3}\left(\frac{1}{r_{c}}\right)^{k-1} \\
& =4834,0724\left(\frac{1}{10}\right)^{1,4-1} \\
& =1924,4788 \mathrm{~K}
\end{aligned}
$$

Tekanan pada titik 4:

Begitu juga dengan tekanan di dalam silinder, mengalami penurunan menjadi $P_{4}$.

$$
\begin{aligned}
P_{4} & =P_{3}\left(\frac{1}{r_{c}}\right)^{k} \\
& =16816,8842\left(\frac{1}{10}\right)^{1,4} \\
& =669,4922 \mathrm{kPa}
\end{aligned}
$$

Volume pada titik 4:

Dari diagram P-v siklus ideal Otto dapat dilihat bahwa $V 4$ sama dengan $V 1$.

$V_{4}=V_{1}=0,00041611 \mathrm{~m}^{3}$ 
Kerja persiklus $3-4$ :

menghasilkan daya dari pembakaran bahan bakar. Laju

Tekanan tinggi yang disertai pembakaran di dalam aliran bahan bakar sebesar $0,00003212 \mathrm{~kg} / \mathrm{det}$ dan daya silinder, membuat piston terdorong kembali ke titik mati poros $\left(W_{b}\right)$ sebesar 22,337 Kw, maka konsumsi bahan bawah (TMB). Gerakan piston tersebut menghasilkan bakar spesifik pada putaran 2000 RPM diperoleh sebagai kerja sebesar $W_{3-4}$.

$$
\begin{aligned}
W_{3-4} & =\frac{m_{m} R\left(T_{4}-T_{3}\right)}{1-k} \\
W_{3-4} & =\frac{0,0005043 \times 0,287(1924,4788-4834,0724)}{1-1,4} \\
& =1,05 \mathrm{Kj}
\end{aligned}
$$
berikut :

$$
\begin{aligned}
s f c & =\frac{m_{f}}{W_{b}} \\
s f c & =\frac{0,00003212 \times \frac{2000}{60} \times 0,5 \times 4}{22,337} \\
& =0,00009586 \mathrm{~kg} / \mathrm{kW}-\mathrm{det}=345,096 \text { gram } / \mathrm{kW}-\mathrm{jam}
\end{aligned}
$$

Proses 4 - 1: Proses pembuangan kalor pada volume konstan

Kalor yang dibuang:

Pada saat torak mencapai titik mati bawah (TMB) kalor dibuang sebesar $Q_{4-1}$.

$$
\begin{aligned}
Q_{4-1}=Q_{\text {out }} & =m_{m} C_{v}\left(T_{1}-T_{4}\right) \\
& =0,0005043 \times 0,718(300-1924,4788) \\
& =(-0,5882) \mathrm{Kj}
\end{aligned}
$$

\section{Tekanan efektif rata-rata}

Didefenisikan sebagai suatu tekanan yang dibayangkan bekerja pada pada permukaan piston pada langkah kerja, sehingga dapat dirumuskan sebagai berikut:

$$
\begin{aligned}
& \text { mep }=\frac{W_{\text {nett }}}{V_{d}} \\
& =\frac{0,8859}{0,0003745} \\
& =2365,5540 \mathrm{kPa}
\end{aligned}
$$

Kerja satu siklus:

Kerja yang dihasilkan dari satu siklus termodinamika adalah sebagai berikut:

$$
\begin{aligned}
W_{\text {nett }} & =W_{1-2}+W_{3-4} \\
& =(-0,1641)+1,05 \\
& =0,8859 \mathrm{Kj}
\end{aligned}
$$

\section{Parameter Performansi Mesin 2000 RPM}

\section{Daya indikator}

Merupakan daya yang dihasilkan dalam silinder motor sehingga merupakan basis perhitungan atau penentuan efisiensi pembakaran atau besarnya laju panas akibat pembakaran di dalam silinder.

Besarnya harga daya indicator $\left(W_{i}\right)$ pada putaran 2000 RPM dapat dirumuskan sebagai berikut :

$$
\begin{aligned}
W_{i} & =\frac{W_{\text {net }} \times N}{n} \\
W_{i} & =\frac{0,8859 \times \frac{2000}{60}}{2} \\
& =14,765 \mathrm{~kW}
\end{aligned}
$$

Untuk 4 silinder $=4 \times 14,765 \mathrm{Kw}=59,06 \mathrm{~kW}$

\section{Daya poros}

Daya poros dapat diukur secara tidak langsung dengan dinamometer. Dinamometer sebenarnya mengukur momen torsi motor. Oleh karena itu memerlukan variabel lain yaitu putaran poros motor yang dapat diukur dengan tachometer. Besar torsi saat 2000 RPM sebesar 106,69 N-m. Hubungan antara momen torsi dengan daya motor adalah sebagai berikut: $W_{b}=2 \pi \cdot n \cdot T$

$$
\begin{aligned}
W_{b} & =2 \pi \cdot \frac{2000}{60} \cdot 106,69 \\
& =22333,7 \mathrm{Nm} / \mathrm{det} \\
& =22,337 \mathrm{~kW}
\end{aligned}
$$

\section{Konsumsi bahan bakar spesifik (Sfc)}

Secara tidak langsung konsumsi bahan bakar spesifik merupakan indikasi efisiensi dalam

\section{Efisiensi volumetrik}

Merupakan indikasi sejauh mana volume sapuan (swept volume) mesin tersebut dapat terisi fluida kerja. Dengan massa udara sebesar $0,00045329 \mathrm{~kg}$, densitas udara $1,2121 \mathrm{~kg} / \mathrm{m3}$, dan besar volume langkah $0,0003745 \mathrm{~m}^{3}$, maka efisiensi volumetrik dapatdihitung dengan rumusan matematika sebagai berikut :

$$
\begin{aligned}
\eta_{v} & =\frac{m_{a}}{\rho_{a} V_{d}} \\
& =\frac{0,00045329}{1,2121 \times 0,0003745} \\
& =0,9985 \\
& =99,85 \%
\end{aligned}
$$

\section{Efisiensi mekanis}

Merupakan perbandingan antara daya poros $\left(W_{b}\right)$ dengan daya indikator $\left(W_{i}\right)$. Dengan daya poros $\left(W_{b}\right)$ sebesar 22,337 $\mathrm{kW}$ dan daya indikator $\left(W_{i}\right)$ sebesar $59,06 \mathrm{~kW}$, maka besarnya efisiensi mekanis dapat diketahui dengan persamaan matematika sebagai berikut:

$$
\begin{aligned}
\eta_{m} & =\frac{W_{b}}{W_{i}} \\
& =\frac{22,337}{59,06} \\
& =0,3782 \\
& =37,82 \%
\end{aligned}
$$

\subsection{Mesin Non VVT-i}

\section{Analisis Termodinamika}

Proses 0 - 1: Langkah hisap, tekanan konstan, katup buang tertutup sedangkan katup masuk terbuka. Udara dianggap sebagai gas ideal. Udara dihisap masuk ke silinder dengan tekanan 1,03 atm atau 104, $3647 \mathrm{kPa}$ pada temperatur $27^{\circ} \mathrm{C}$ atau $300 \mathrm{~K}$, maka: $P_{0}=P_{1}=104$, $3647 \mathrm{kPa}$

$$
\begin{aligned}
& T_{1}=300 \mathrm{~K} \\
& r_{c}=9 \\
& \mathrm{~B}=7,2 \mathrm{~cm}
\end{aligned}
$$




$$
\begin{aligned}
& \mathrm{S}=9,18 \mathrm{~cm} \\
& \mathrm{R}=0,287 \mathrm{~kJ} / \mathrm{kg}-\mathrm{K} \\
& C_{V}=0,718 \mathrm{~kJ} / \mathrm{kg}-\mathrm{K}
\end{aligned}
$$

Volume langkah:

Merupakan volume dari langkah torak dari titik mati bawah (TMB) ke titik mati atas (TMA). Kapasitas 4 silinder adalah $1298 c c$, maka volume langkah untuk satu silinder:

$$
\begin{aligned}
& V_{d}=\frac{1298}{4} \\
& V_{d}=324,5 c c=0,0003245 \mathrm{~m}^{3}
\end{aligned}
$$

Volume sisa:

Didefenisikan sebagai volume minimum silinder pada saat torak berada di titik matiatas (TMA). Dengan rasio kompresi sebesar 10:1 dan volume langkah sebesar $0,0003245 \mathrm{~m}^{3}$ maka besarnya volume sisa:

$$
\begin{aligned}
r_{a} & =\frac{V_{C}+V_{d}}{V_{c}} \\
& =\frac{V_{C}+0,0003245}{V_{c}}=10 \\
V_{C} & =0,00003606 \mathrm{~m}^{3}
\end{aligned}
$$

Volume pada titik 1:

Merupakan hasil penjumlahan volume langkah $(V d)$ dengan volume sisa $\left(V_{c}\right)$.

$$
\begin{aligned}
V_{1} & =V_{C}+V_{d} \\
& =0,00003606+0,0003245 \\
& =0,00036056 \mathrm{~m}^{3}
\end{aligned}
$$

Massa campuran bahan bakar dan udara:

$$
\text { Dengan tekanan } 1 \text { atm atau } 104,3647 \mathrm{kPa} \text { dan }
$$

volume silinder $0,00036056 \mathrm{~m}^{3}$ pada

temperatur $300 \mathrm{~K}$, massa campuran bahan bakar dan udara adalah :

$$
\begin{aligned}
m_{m} & =\frac{P_{1} V_{1}}{R T_{1}} \\
& =\frac{104,3647 \times 0,00036056}{0,287 \times 300} \\
& =0,0004370 \mathrm{~kg}
\end{aligned}
$$

Massa udara pembakaran dan massa bahan bakar:

Sejumlah udara dihisap masuk ke dalam silinder dengan perbandingan 14,7:1terhadap bahan bakar pada tekanan konstan. Udara mengisi ruangan silinder yang bertambah besar seiring bergeraknya torak dari titik mati atas (TMA) ke titik mati bawah (TMB). Untuk $1 \mathrm{~kg}$ bahan bakar diperlukan $14,7 \mathrm{~kg}$ udara dengan massa campuran $(\mathrm{mm})$ sebesar $0,0004425 \mathrm{~kg}$ serta diasumsikan residu gas hasil pembakaran $4 \%$ dari siklus sebelumnya, maka besarnya massa udara dan massa bahan bakar adalah :

$$
\begin{aligned}
& m_{a}=\left(\frac{14,7}{15,7}\right) \times 0,96 \times 0,0004370 \mathrm{~kg}=0,00039279 \mathrm{~kg} \\
& m_{f}=\left(\frac{1}{15,7}\right) \times 1 \times 0,0004370 \mathrm{~kg}=0,000027834 \mathrm{~kg}
\end{aligned}
$$

Densitas udara $\left(P_{a}\right)$ :

Tekanan dan temperatur udara sekitar mesin dapat digunakan untuk mencari densitas udara dengan persamaan matematika sebagai berikut:

$$
\begin{aligned}
P_{a} & =\frac{P_{1}}{R T_{1}} \\
& =\frac{104,3647}{0,287 \times 300} \\
& =1,2121 \mathrm{~kg} / \mathrm{m}^{3}
\end{aligned}
$$

Proses 1 - 2: Langkah kompresi isentropik, semua katup tertutup. Torak bergerak darititik mati bawah (TMB) ke titik mati atas (TMA). Tekanan pada titik 2 : Campuran bahan bakar dan udara yang berada di dalam silinder ditekan dandimampatkan oleh torak yang bergerak ke titik mati atas (TMA). Akibatnya, tekanan dalam silinder naik menjadi $P 2$.

$$
\begin{aligned}
P_{2} & =P_{1}\left(r_{c}\right)^{k} \\
& =104,3647 \times(10)^{1,4} \\
& =2621,522 \mathrm{kPa}
\end{aligned}
$$

Temperatur pada titik 2:

Campuran bahan bakar dan udara yang dimanfaatkan oleh torak yang bergerak ke titik mati atas (TMA) juga mengakibatkan suhu dalam silinder naik menjadi $T_{2}$.

$$
\begin{aligned}
T_{2} & =T_{1}\left(r_{c}\right)^{k-1} \\
& =300 \times(10)^{1,4-1} \\
& =753,5659 \mathrm{~K}
\end{aligned}
$$

Volume pada titik 2 :

$$
\begin{aligned}
V_{2} & =\frac{m_{m} R T_{2}}{P_{2}} \\
& =\frac{0,0004370 \times 0,287 \times 753,5659}{2621,522} \\
& =0,00003605 \mathrm{~m}^{3}
\end{aligned}
$$

$V_{2}=V_{C}$

\section{Kerja persiklus $1-2$ :}

Kerja yang diserap selama langkah kompresi isentropik untuk satu silinder dalam satu siklus adalah sebagai berikut :

$$
\begin{aligned}
W_{1-2} & =\frac{m_{m} R\left(T_{2}-T_{1}\right)}{1-k} \\
W_{1-2} & =\frac{0,0004370 \times 0,287(753,5659-300)}{1-1,4} \\
& =(-0,1422) \mathrm{kJ}
\end{aligned}
$$

Proses 2-3: Penambahan kalor pada volume konstan. Kalor masuk:

Bahan bakar yang digunakan adalah PERTAMAX dengan nilai kalori bahan bakar $46000 \mathrm{~kJ} / \mathrm{kgdan}$ diasumsikan terjadi pembakaran sempurna, $\eta_{a}=1$.

$Q_{\text {in }}=m_{f} Q_{H V} \eta_{a}$

$$
=0,00002783 \times 46000 \times 1=1,2801 \mathrm{~kJ}
$$

\section{Temperatur pada titik 3:}

Dengan menggunakan persamaan matematika $Q_{\text {in }}=$ $m_{m} C_{V}\left(T_{3}-T_{2}\right)$, maka $T_{3}$ dapat diketahui :

$T_{3}=\frac{Q_{\text {in }}+m_{m} C_{V} T_{2}}{m_{m} C_{V}}$

$T_{3}=\frac{1,2801+0,0004370 \times 0,718 \times 753,5659}{0,0004370 \times 0,718}$

$T_{3}=4833,357 \mathrm{~K}$

$T_{3}=T_{\text {maks }}$ 
Volume pada titik 3:

Dari diagram P-v siklus Otto ideal dapat dilihat bahwa $V_{3}$ sama dengan $V_{2}$.

$V_{3}=V_{2}=0,00003605 m^{3}$

Tekanan pada titik 3:

Seiring dengan bertambahnya temperatur selama siklus tertutup volume konstan, maka bertambah pula tekanan di dalam silinder.

$$
\begin{aligned}
P_{3} & =P_{2} \frac{T_{3}}{T_{2}} \\
& =2621,522\left(\frac{4833,357}{753,5659}\right) \\
& =16814,391 \mathrm{kPa}
\end{aligned}
$$
siklus.

Tekanan tersebut merupakan tekanan maksimum

$$
P_{3}=P_{\text {maksimum }}
$$

Proses 3 - 4: Langkah Ekspansi isentropik

Temperatur pada titik 4:

Setelah torak mencapai titik mati bawah (TMB) sejumlah kalor dikeluarkan dari dalam silinder sehingga Untuk 4 silinder $=4$ x 14,765 Kw $=51,326 \mathrm{~kW}$ temperatur fluida kerja akan turun menjadi $T 4$.

$$
\begin{aligned}
T_{4} & =T_{3}\left(\frac{1}{r_{c}}\right)^{k-1} \\
& =4833,357\left(\frac{1}{10}\right)^{1,4-1} \\
& =1924,194 \mathrm{~K}
\end{aligned}
$$

Tekanan pada titik 4:

Begitu juga dengan tekanan di dalam silinder, mengalami penurunan menjadi $P_{4}$.

$$
\begin{aligned}
P_{4} & =P_{3}\left(\frac{1}{r_{c}}\right)^{k} \\
& =16814,391\left(\frac{1}{10}\right)^{1,4} \\
& =669,3929 \mathrm{kPa}
\end{aligned}
$$

Volume pada titik 4:

Dari diagram P-v siklus ideal Otto dapat dilihat bahwa $V 4$ sama dengan $V 1$.

$V_{4}=V_{1}=0,00036056 \mathrm{~m}^{3}$

Kerja persiklus $3-4$ :

Tekanan tinggi yang disertai pembakaran di dalam silinder, membuat piston terdorong kembali ke titik mati bawah (TMB). Gerakan piston tersebut menghasilkan kerja sebesar $W_{3-4}$.

$$
\begin{aligned}
W_{3-4} & =\frac{m_{m} R\left(T_{4}-T_{3}\right)}{1-k} \\
W_{3-4} & =\frac{0,0004370 \times 0,287(1924,194-4833,357)}{1-1,4} \\
& =0,9121 \mathrm{Kj}
\end{aligned}
$$

Proses 4 - 1: Proses pembuangan kalor pada volume konstan

Kalor yang dibuang:

Pada saat torak mencapai titik mati bawah (TMB) kalor dibuang sebesar $Q_{4-1}$.

$$
\begin{aligned}
Q_{4-1}=Q_{\text {out }} & =m_{m} C_{v}\left(T_{1}-T_{4}\right) \\
& =0,0004370 \times 0,718(300-1924,194) \\
& =(-0,5096) \mathrm{Kj}
\end{aligned}
$$

Kerja satu siklus :

Kerja yang dihasilkan dari satu siklus termodinamika adalah sebagai berikut:

$$
\begin{aligned}
W_{\text {nett }} & =W_{1-2}+W_{3-4} \\
& =(-0,1422)+0,9121 \\
& =0,7699 \mathrm{~kJ}
\end{aligned}
$$

\section{Parameter Performansi Mesin Non VVT-i 2000 RPM}

\section{Daya indikator}

Merupakan daya yang dihasilkan dalam silinder motor sehingga merupakan basis perhitungan atau penentuan efisiensi pembakaran atau besarnya laju panas akibat pembakaran di dalam silinder.

Besarnya harga daya indikator $\left(W_{i}\right)$ pada putaran 2000 RPM dapat dirumuskan sebagai berikut :

$$
\begin{aligned}
W_{i} & =\frac{W_{\text {net }} \times N}{n} \\
W_{i} & =\frac{0,7699 \times \frac{2000}{60}}{2} \\
& =12,831 \mathrm{~kW}
\end{aligned}
$$

\section{Daya poros}

Daya poros dapat diukur secara tidak langsung dengan dinamometer. Dinamometer sebenarnya mengukur momen torsi motor. Oleh karena itu memerlukan variabel lain yaitu putaran poros motor yang dapat diukur dengan tachometer. Besar torsi saat 2000 RPM sebesar 89,49 N-m. Hubungan antara momen torsi dengan daya motor adalah sebagai berikut:

$$
\begin{aligned}
W_{b} & =2 \pi \cdot n \cdot T \\
W_{b} & =2 \pi \cdot \frac{2000}{60} \cdot 89,49 \\
& =18733,2 \mathrm{Nm} / \mathrm{det} \\
& =18,7332 \mathrm{~kW}
\end{aligned}
$$

\section{Konsumsi bahan bakar spesifik (Sfc)}

Secara tidak langsung konsumsi bahan bakar spesifik merupakan indikasi efisiensi dalam menghasilkan daya dari pembakaran bahan bakar. Laju aliran bahan bakar sebesar $0,00002783 \mathrm{~kg} /$ det dan daya poros $\left(W_{b}\right)$ sebesar $18,7332 \mathrm{Kw}$, maka konsumsi bahan bakar spesifik pada putaran 2000 RPM diperoleh sebagai berikut :

$\begin{aligned} s f c & =\frac{m_{f}}{W_{b}} \\ s f c & =\frac{0,00002783 \times \frac{2000}{60} \times 0,5 \times 4}{18,7332} \\ & =0,000099039 \mathrm{~kg} / \mathrm{kW}-\mathrm{det}=356,5404 \mathrm{gram} / \mathrm{kW}-\mathrm{jam}\end{aligned}$ dibayangkan bekerja pada pada permukaan piston pada langkah kerja, sehingga dapat dirumuskan sebagai berikut:

$$
\begin{aligned}
\text { mep } & =\frac{W_{\text {nett }}}{V_{d}} \\
& =\frac{0,7699}{0,0003245} \\
& =2372,573 \mathrm{kPa}
\end{aligned}
$$




\section{Efisiensi volumetrik}

Merupakan indikasi sejauh mana volume sapuan putaran mesin tinggi sekitar $5000 \mathrm{rpm}$ sampai $6000 \mathrm{rpm}$, (swept volume) mesin tersebut dapat terisi fluida kerja. akan melewati puncak torsinya dan mengakibatkan torsi Dengan massa udara sebesar $0,00039279 \mathrm{~kg}$, densitas turun.

udara $1,2121 \mathrm{~kg} / \mathrm{m} 3$, dan besar volume langkah $0,0003245 \mathrm{~m}^{3}$, maka efisiensi volumetrik dapat dihitung dengan rumusan matematika sebagai berikut :

$$
\begin{aligned}
\eta_{v} & =\frac{m_{a}}{\rho_{a} V_{d}} \\
= & \frac{0,00039279}{1,2121 \times 0,0003245} \\
& =0,9986 \\
& =99,86 \%
\end{aligned}
$$

\section{Efisiensi mekanis}

Merupakan perbandingan antara daya poros $\left(W_{b}\right)$ dengan daya indikator $\left(W_{i}\right)$. Dengan daya poros $\left(W_{b}\right)$ sebesar $18,7332 \mathrm{~kW}$ dan daya indikator $\left(W_{i}\right)$ sebesar $51,326 \mathrm{~kW}$, maka besarnya efisiensi mekanis dapat diketahui dengan persamaan matematika sebagai berikut:

$$
\begin{aligned}
\eta_{m} & =\frac{W_{b}}{W_{i}} \\
& =\frac{18,7332}{51,326} \\
& =0,3649 \\
& =36,49 \%
\end{aligned}
$$

Berikut adalah tabel dan grafik performansi mesin:

Tabel 1. Analisa perhitungan hasil Torsi, Daya dan SFC

\begin{tabular}{ccccccc}
\multirow{2}{*}{$\begin{array}{c}\text { Putaran } \\
\text { Mesin } \\
(\text { RPM })\end{array}$} & \multicolumn{2}{c}{ Torsi (Nm) } & \multicolumn{2}{c}{ Daya (kW) } & SFC (gr/kW-jam) \\
& & & & & & \\
& & & & & & \\
& VVT-i & VVT-i & VVT-i & VVT-i & VVT-i & VVT-i \\
\hline 2000 & 106.69 & 89.49 & 22.337 & 18.733 & 345.096 & 356.54 \\
3000 & 119.63 & 95.98 & 37.564 & 30.137 & 307.8 & 332.42 \\
4000 & 118.48 & 95.90 & 49.603 & 40.15 & 310.78 & 332.676 \\
5000 & 114.56 & 100.98 & 59.953 & 52.846 & 321.44 & 315.972 \\
6000 & 98.13 & 91.59 & 61.625 & 57.518 & 375.12 & 348.336 \\
\hline
\end{tabular}

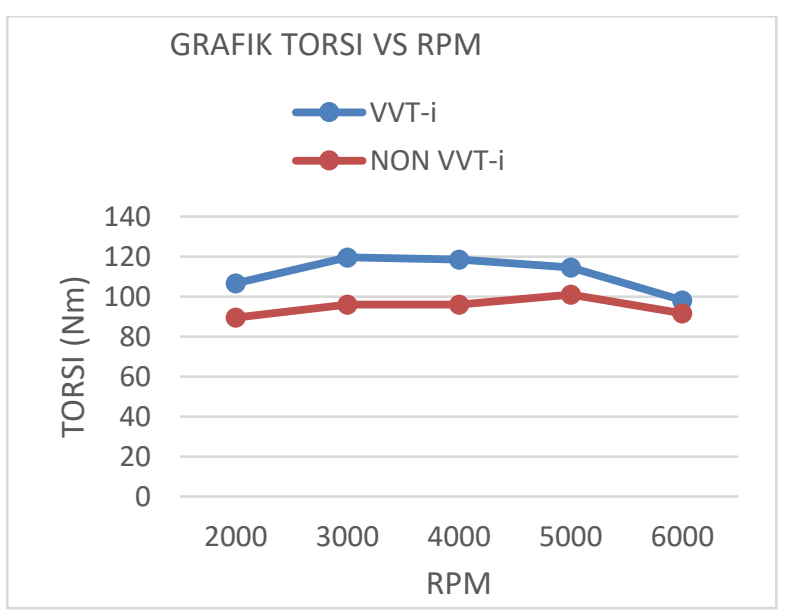

Gambar 2. Grafik Torsi Mesin VVT-i dan NON VVT-i

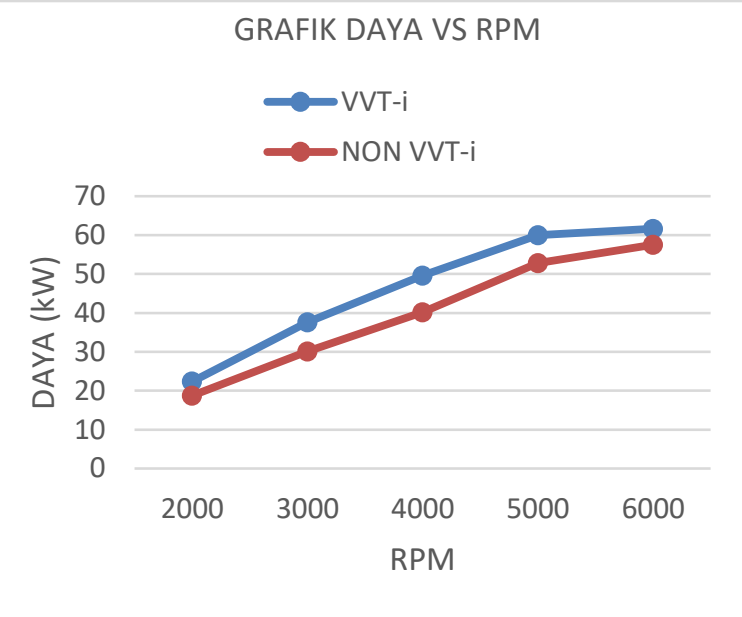

Gambar 3. Grafik Daya Mesin VVT-I dan NON VVT-i

Pada grafik daya mesin diatas menunjukkan bahwa setiap putaran mesin mengalami kenaikan daya pada mesin $V V T-i$ dan Non $V V T-i$. Daya mesin pada teknologi $V V T-i$ lebih besar ketimbang daya mesin Non VVT-i. Pada putaran mesin yang sama yaitu $2000 \mathrm{rpm}$, daya yang dihasilkan mesin mobil berteknologi $V V T-i$ sebesar 23,337 kW, sedangkan untuk mesin mobil berteknologi non $V V T$-i yang dihasilkan sebesar $18,733 \mathrm{~kW}$. Sehingga kenaikannya sebesar 19,72\%. Begitu juga dengan putaran mesin lainnya, terjadi kenaikan daya yang dihasilkan mesin mobil berteknologi $V V T-i$.

GRAFIK SFC VS RPM

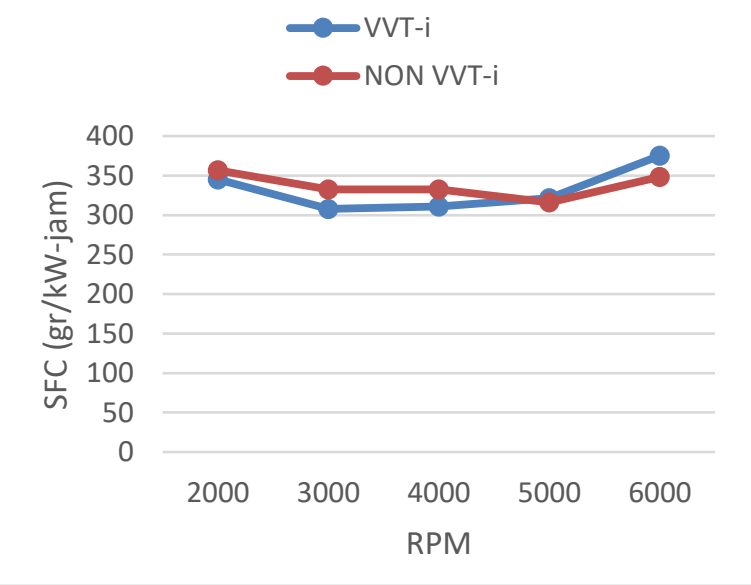

Gambar 4. Grafik SFC Mesin VVT-i dan NON VVT-i

Pada grafik SFC diatas menunjukkan bahwa pada putaran mesin stabil antara $2000 \mathrm{rpm}$ sampai $4000 \mathrm{rpm}$ konsumsi bahan bakar pada mesin $V V T-i$ lebih sedikit ketimbang konsumsi bahan bakar pada mesin Non VVT$i$. Namun pada putaran mesin tinggi, konsumsi bahan bakar mesin VVT-i lebih besar, karena tenaga yang

Pada grafik torsi mesin diatas menunjukkan bahwa dibutuhkan mesin $V V T-i$ lebih besar saat berada di pada mesin $V V T-i$ torsi yang dihasilkan lebih besar dari putaran mesin yang besar. 


\section{Kesimpulan}

Berdasarkan hasil perhitungan analisis performansi daya mesin mobil VVT-I dan NON VVT-I menggunakan dynotest dapat disimpulkan bahwa pada putaran mesin yang sama yaitu $2000 \mathrm{rpm}$, daya yang dihasilkan mesin mobil berteknologi VVT-i sebesar 23,337 kW, sedangkan untuk mesin mobil berteknologi non $V V T$-i yang dihasilkan sebesar $18,733 \mathrm{~kW}$. Sehingga kenaikannya sebesar $19,72 \%$. Begitu juga dengan putaran mesin lainnya, terjadi kenaikan daya yang dihasilkan mesin mobil berteknologi $V V T-i$,pada putaran yang sama yaitu $2000 \mathrm{rpm}$, konsumsi bahan bakar mobil berteknologi VVT-i sebesar 345,096 gr/kW- jam, sedangkan untuk mobil berteknologi non $V V T-i$ sebesar $356,54 \mathrm{gr} / \mathrm{kW}$ - jam. Ini menunjukkan bahwa pada saat putaran mesin stabil, konsumsi bahan bakar teknologi $V V T-i$ lebih sedikit ketimbang non $V V T-i$. Namun pada saat putaran mesin tinggi yaitu $5000 \mathrm{rpm}$ dan $6000 \mathrm{rpm}$ konsumsi bahan bakar mobil teknologi VVT-i lebih besar dari non $V V T-i$, karena tenaga yang dibutuhkan mesin VVT-i lebih besar saat berada di putaran mesin yang besar serta adanya efisiensi mekanis pada mesin mobil berteknologi VVT-i dan non VVT-i juga menunjukkan bahwa pada putaran mesin yang stabil antara $3000 \mathrm{rpm}-4000 \mathrm{rpm}$ persentase efisiensi lebih besar ketimbang pada putaran mesin lainnya. Pada putaran mesin $3000 \mathrm{rpm}$, mesin mobil VVT-i menghasilkan $42,40 \%$ sementara pada non VVT-i menghasilkan 39,11\%. Pada putaran mesin $4000 \mathrm{rpm}$, mesin mobil VVT-i menghasilkan $41,99 \%$ sementara pada non VVT-i menghasilkan 39,11\%.

\section{Daftar Rujukan}

[1] Anonim, Gasoline Engine. Jakarta: PT. Astra Daihatsu Motor, 2015.

[2] BPM. Arends and H. Berenschot, Motor Bensin. Jakarta: Erlangga, 1980.

[3] W. Suyanto, Teori Motor Bensin. Jakarta: Direktorat Jenderal Pendidikan Tinggi, Proyek Pengembangan Lembaga Pendidikan Tenaga Pendidikan, 1989.

[4] F. M. Siregar, "Kajian Teoritis Performansi Mesin Berteknologi VVT-I Dan Non VVT-i," Medan, 2009.

[5] T. B. Sitorus, "Tinjauan Teoritis Performansi Mesin Berteknologi VVT-i,” Jurnal Dinamis, vol. I, no. 5, 2009.

[6] A. Y. Kurniawan, "Identifikasi Sistem VVT-i Kijang Innova 1TR-FE," Universitas Negeri Semarang, Semarang, 2015.

[7] K. ASTAWA, "Pencapaian Performa Pada Katup Variabel Timing Fixed Timing Untuk Mesin Yang Optimal," Jurnal Teknik Industri, vol. 11, no. 1, 2012, doi:

10.22219/jtiumm.vol11.no1.68-74.

[8] M. J. Moran, Termodinamika Teknik, 2nd ed. Jakarta: Erlangga, 2007.

[9] J. B. Heywood, Internal Combustion Engine Fundamentals. New York: Mcgraw Hill Book Company, 1988.

[10] N. Soenarta and S. Furuhama, Motor Serba Guna. Jakarta: Pradnya Paramita, 1995. 